\title{
Familial Mediterranean Fever: What associations to screen for? (A Review)
}

\author{
Salem Bouomrani ${ }^{*}$ and Ines Masmoudi ${ }^{2}$ \\ ${ }^{1}$ Department of Internal medicine, Military Hospital of Gabes, Tunisia \\ ${ }^{2}$ Sfax Faculty of Medicine, University of Sfax, Tunisia \\ *Corresponding author: Salem Bouomrani, Department of Internal medicine, Military Hospital of Gabes, Tunisia
}

\begin{abstract}
Familial Mediterranean Fever (FMF) is the most common and best known of hereditary recurrent fever or periodic fever syndromes. It was described in 1945 and genetically characterized in 1992; caused by a point mutation in the "MEFV" gene located on the short arm of chromosome 16. It is particularly frequent among Sephardic Jews, Armenians, Turks and Middle Eastern Arabs where the prevalence can reach $1 / 2000$ to $1 / 1000$. Recent publications objectified its frequent association with other diseases and/or syndromes, particularly those of autoimmune, genetic, and auto-inflammatory origin. The objective of this review is to familiarize healthcare professionals with the main associations to look for in patients followed for FMF. The early detection of these associations makes it possible to improve the management and the prognosis of patients with FMF.
\end{abstract}

Keywords: Familial Mediterranean Fever; Periodic fever; Diseases; Pyrine; Association; Chronic inflammation; MEFV gene

\section{Introduction}

Familial Mediterranean Fever (FMF) is an auto inflammatory disease with genetic transmission described in 1945 [1] and its characteristic mutation identified in 1992 [2,3]. It is particularly frequent among Sephardic Jews, Armenians, Turks, and Middle Eastern Arabs where the prevalence can reach 1/2000 among Jews and $1 / 1000$ for Turks and Armenians [1,4]. It is caused by a point mutation in the "MEFV" gene located on the short arm of chromosome $16[1,4,5]$. This mutation leads to the production of a mutant protein "pyrine" and thus causes a disruption of the normal inflammatory response and cellular apoptosis [4,5]. Clinically, FMF is characterized by painful paroxysmal and febrile peritoneal, pleural, and joint attacks, which can be associated with various systemic manifestations: cutaneous, neurological, cardiac, urogenital and hematopoietic [1-4].

Several diagnostic criteria, the most used of which are those of Livneh [6], help in the positive diagnosis of this disease but the confirmation is genetic based on the demonstration of mutations in the gene "MEFV" of which there are more than twenty. The most frequent of these mutations are: M694V, M694I, V726A, and E148Q $[4,7]$. Recent publications have objectified its frequent association with other diseases and/or syndromes, the common denominator of which is genetic predisposition, immune dysfunction, and autoinflammation. It is therefore important for health professionals to know these associations in order to detect them in time and initiate appropriate care without delay. This approach is the only guarantee to improve the prognosis of this disease, often reserved.

\section{FMF and Its Most Frequent Associations}

Several associations have been described with the FMF; the most frequent are: spondyloarthropathies, systemic vasculitis, and inflammatory bowel disease (IBD).

\section{FMF and spondylarthropathies}

a significant association between FMF and spondylarthropathies in general and ankylosing spondylitis in particular was reported by several authors [8-11]. In fact, 7.5\% of subjects with FMF in the Akar $\mathrm{S}$ et al series had associated ankylosing spondylitis. The relative risk (RR) of having spondyloarthropathy and specifically ankylosing spondylitis was also very high in the first-degree parents of a subject with FMF compared to the general population (PR $=3.3$ and 2.9 respectively) [11]. 
This association is reinforced by the particular frequency of enthesopathies in subjects with FMF [12] suggesting that the mutant MEFV gene could partially promote such an association $[11,13]$. In addition, a statistically significant association has been demonstrated between mutations in the MEFV gene; in particular that of type M694V, and ankylosing spondylitis (even without known FMF): $10.7 \%$ Vs only $4.2 \%$ in the general population, $\mathrm{p}=0.06$ in the series of yigit S et al [10] and $22.3 \%$ Vs only $9.7 \%$ for all "nonsense" mutations of the MEFV gene in the Cosan F et al series [14].

\section{FMF and systemic vasculitis}

The most frequent association is with Henöch-Shönlein syndrome or purpura (HSS) $[15,16]$. In fact, in the series of 68 patients with HSS of Altug $U$ et al, $26 \%$ had an associated FMF [17]. This particularly frequent association between HSS and FMF seriously suggests that MEFV could be the causative gene for HSS; the etiopathogenesis of which has not yet been elucidated [18]: in the series of 72 children with HSS of Dogan CS et al. [19] 11 (14.4\%) had the MEFV gene mutation in its heterozygous form, 5 (6.6\%) in its homozygous form, and $2(2.6 \%)$ in its heterozygous composite form. In addition, seven of these patients presented at the same time two distinct mutations of the MEFV gene which was clearly significant compared to the general population (9.2\% Vs $1 \%$ ). Other systemic vasculitides are also reported to be associated with FMF: panarteritis nodosa, Protracted Febrile Myalgia Syndrome (PFMS-syndrome), Behçet's disease [11,17,20-22], and Takayasu arteritis $[23,24]$.

To approach the mechanism of these associations, the study by Aytekin $\mathrm{S}$ et al seems very interesting by revealing a particularly high frequency of vascular anomalies on capillaroscopy during FMF (capillary enlargement and microhemorrhages). These anomalies which characterize systemic vasculitides, suggest a systemic angiitis of the small vessels as mediator of the FMF clinic [22]. This hypothesis is reinforced by the original observation of Girisgen I et al. [16] reporting the concomitant association of an FMF with two systemic vasculitides (HSS and panarteritis nodosa).

In summary, among the systemic vasculitis associated with FMF, HSS and classic panarteritis nodosa are the most frequent [11,24]; next come the PFMS-syndrome and Behçet's disease [11]. The other systemic angiitis are more exceptional [23,24].

\section{FMF and inflammatory bowel disease (IBD)}

IBD (Crohn's disease and ulcerative colitis) are far from rare during FMF [11,25-28]. In fact, 22 (15.4\%) in the series of 78 patients suffering from FMF of Beser OF et al, had concomitant endoscopically and histologically confirmed IBD [26]. Likewise, the presence of the MEFV gene mutation was significantly found in patients with histologically confirmed IBD: $28 \%$ in ulcerative colitis, and 22.6\% in Crohn's disease Vs only 9.9\% in the healthy controls; $p=0.006$ [27].

\section{FMF and multiple sclerosis (MS)}

This association reported by several authors [11,29-32] but too long controversial [33] has just been recently proven by the large national study of Yahalom G et al. [34] (one of the largest series of FMF) where the frequency of multiple sclerosis in patients with FMF was $0.075 \%=$ three times that of the general population ( $p=0.0057$ ); in addition, the presence of the M694V mutation worsened the clinical picture of multiple sclerosis in these patients. On the other hand, the study of Unal A et al. [29] had shown a significant frequency of the mutation of the MEFV gene in patients with multiple sclerosis compared to the general population: $38 \%$ Vs only $11 \%, p<0.0001$. These findings suggest the mutation of the MEFV gene as a potential predisposing factor for multiple sclerosis; in particular the E148Q type mutation [32].

\section{FMF and rheumatoid arthritis}

This association is increasingly reported in the world literature [35-39], and a significantly higher frequency of anti-citrullinated protein (anti-CCP) autoantibodies (specific for rheumatoid arthritis) has been found in patients with FMF: $14.5 \%$ Vs only $4.7 \%$ in the general population ( 3 times higher); their presence was significantly associated with arthritis during FMF [40].

\section{FMF and jvenile idiopathic arthritis (JIA)}

This association is also far from rare. It has been reported by several authors [41-43]. It has been shown that the frequency of the specific M694V mutation of the MEFV gene during JIA is around $10 \%$, and its presence makes the JIA more severe and more resistant to the usual treatment requiring the use of biotherapy [41]. Also, the presence of all types of MEFV mutations was significantly higher during JIA compared to the general population: $14.28 \%$ Vs only $5 \%, p<0.01 \%$ [41]. Therefore, it is recommended to screen for MEFV gene mutations in children presumed to have JIA, especially those of male sex, if enthesopathies and if negative anti-nuclear antibodies [44].

\section{FMF and non-alcoholic fatty liver disease (NAFLD)}

in the series of Rimar D etal, $74 \%$ of patients with FMF presented NAFLD ranging from simple hepatic steatosis (5 patients/21) to non-alcoholic steatohepatitis (NASH): 3 patients/21, and cirrhosis on NASH: 7 patients/21; and this apart from any underlying metabolic syndrome suggesting a strong association between FMF and NAFLD [45].

\section{FMF and its rarer associations}

Other rarer associations have been reported, with: systemic lupus erythematosus [46-48], sarcoidosis, Blau syndrome [49], Kartagener syndrome [50], Gitelman syndrome [51], 
Fabry syndrome [52 ], celiac disease [53], polymyositis [54], juvenile dermatomyositis [55], beta-thalassemia [56], atrophic polychondritis [57], fibromyalgia [58], eosinophilic gastroenteritis [59], and tumour necrosis factor receptor-1 syndrome (TRAPS syndrome).

\section{Conclusion}

Knowledge of these associations, especially the most common, is very useful for healthcare professionals caring for patients with FMF. Their diagnosis is not always easy since many of these diseases can cause the same symptoms or have similar clinical presentations. The early detection of these associations makes it possible to improve the management and the prognosis of patients with FMF

\section{Conflicts of Interest}

None.

\section{References}

1. Etem E, Sukriye Derya Deveci, Deniz Erol, Huseyin Yuce, Halit Elyas, et al. (2010) Familial Mediterranean fever: a retrospective clinical and molecular study in the East of Anatolia region of Turkey. The Open Rheum J 4:1-6.

2. The French FMF consortium (1997) A candidate gen for familiar Mediterranean fever. Nat Genetics 17: 25-31.

3. (1997) International FMF consortium: ancient missense mutations in a new member of the RoRet gene family are likely to cause familial Mediterranean fever. The International FMF Consortium. Cell 90: 797807.

4. Medlej-Hashim M, Loiselet J, Lefranc G, Mégarbané A (2004) Familial Mediterranean fever (FMF): from diagnosis to treatment. Sante 14(4): 261-266.

5. Tidow N, Chen X, Müller C, Kawano S, Gombart AF, et al. (2000) Hematopoietic-specific expression of MEFV, the gene mutated in familial Mediterranean fever, and subcellular localization of its corresponding protein, pyrin. Blood 95(4): 1451-1455.

6. Livneh A, Lagevitz P, Zemer D, Zaks N, Kees S, et al. (1997) Criteria for the diagnosis of familial Mediterranean fever. Arthritis Rheum 40: 1879-85.

7. Touitou I (2000) The spectrum of mutations. II International conference of familial Mediterranean fever. Antalya, Turkey, pp. 3-6.

8. Estublier C, Stankovic Stojanovic K, Bergerot JF, Broussolle C, Sève P, et al. (2013) Myositis in a patient with familial Mediterranean fever and spondyloarthritis successfully treated with anakinra. Joint Bone Spine 80(6): 645-649.

9. Akar S, Soysal O, Balci A, Solmaz D, Gerdan V, et al. (2013) High prevalence of spondyloarthritis and ankylosing spondylitis among familial Mediterranean fever patients and their first-degree relatives: further evidence for the connection. Arthritis Res Ther 15(1): R21.

10. Yigit S, Inanir A, Karakus N, Kesici E, Bozkurt N, et al. (2012) Common Mediterranean fever (MEFV) gene mutations associated with ankylosing spondylitis in Turkish population. Dis Markers. 33(3): 113-118.

11. Aksu K, Keser G (2011) Coexistence of vasculitides with familial Mediterranean fever. Rheumatol Int 31(3): 1263-1274.

12. Ozkan F, Cetin GY, Inci MF, Bakan B, Yuksel M, et al. (2013) Increased enthesopathy in patients with familial Mediterranean fever: evaluation with a new sonographic enthesitis index. J Ultrasound Med 32(2): 325332.
13. Tufan A, Mercan R, Tezcan ME, Kaya A, Bitik B, et al. (2013) Enthesopathy in patients with familial Mediterranean fever: increased prevalence in M694 V variant. Rheumatol Int 33(8): 1933-1937.

14. Cosan F, Ustek D, Oku B, Duymaz-Tozkir J, Cakiris A, et al. (2010) Association of familial Mediterranean fever-related MEFV variations with ankylosing spondylitis. Arthritis Rheum 62(11): 3232-3236.

15. Cabral M, Conde M, Brito MJ, Almeida H, Melo Gomes JA, et al. (2011) Protracted Febrile Myalgia Syndrome with Henoch-Schönlein Purpura: an atypical presentation of Familial Mediterranean Fever. Acta Reumatol Port 36(1): 69-74.

16. Girisgen I, Sonmez F, Koseoglu K, Erisen S, Yilmaz D, et al. (2012) Polyarteritis nodosa and Henoch-Schönlein purpura nephritis in a child with familial Mediterranean fever: a case report. Rheumatol Int 32(2): 529-533.

17. Altug U, Ensari C, Sayin DB, Ensari A (2013) MEFV gene mutations in Henoch-Schönlein purpura. Int J Rheum Dis 16(3): 347-51.

18. He X, Yu C, Zhao P, Ding Y, Liang X, et al. (2013) The genetics of HenochSchönlein purpura: a systematic review and meta-analysis. Rheumatol Int 33(6): 1387-1395.

19. Dogan CS, Akman S, Koyun M, Bilgen T, Comak E, et al. (2013) Prevalence and significance of the MEFV gene mutations in childhood HenochSchönlein purpura without FMF symptoms. Rheumatol Int 33(2): 377380.

20. Luger S, Harter PN, Mittelbronn M, Wagner M, Foerch C, et al. (2013) Brain stem infarction associated with familial Mediterranean fever and central nervous system vasculitis. Clin Exp Rheumatol 31(3 Suppl 77): 93-95.

21. Ozçakar ZB, Yalçınkaya F (2011) Vascular comorbidities in familial Mediterranean fever. Rheumatol Int 31(10): 1275-1281.

22. Aytekin S, Aydin F, Akpolat T, Senturk N, Turanli AY, et al. (2011) Evaluation of nailfold capillaries in familial Mediterranean fever patients. Clin Rheumatol 30(2): 255-257.

23. Alibaz-Oner F, Yilmaz N, Can M, Direskeneli H (2012) A case of Takayasu's arteritis associated with familial Mediterranean fever. Clin Exp Rheumatol 30(3 Suppl 72): S117.

24. Zihni FY, Kalfa M, Ocakçı PT, Tarhan F, Parildar M, et al. (2012) Coexistence of Takayasu's arteritis with familial Mediterranean fever. Rheumatol Int 32: 1675-1678.

25. Kuloğlu Z, Kansu A, Ustündağ G, Birsin Özçakar Z, Ensari A, et al. (2012) An infant with severe refractory Crohn's disease and homozygous MEFV mutation who dramatically responded to colchicine. Rheumatol Int 32(3): 783-785.

26. Beşer OF, Kasapçopur O, Cokuğraş FC, Kutlu T, Arsoy N, et al. (2013) Association of inflammatory bowel disease with familial Mediterranean fever in Turkish children. J Pediatr Gastroenterol Nutr 56(5): 498-502.

27. Akyuz F, Besisik F, Ustek D, Ekmekçi C, Uyar A, et al. (2013) Association of the MEFV gene variations with inflammatory bowel disease in Turkey. J Clin Gastroenterol 47: 23-27.

28. Uslu N, Demir H, Balta G, Saltik-Temizel IN, Ozen H, et al. (2010) Hemophagocytic syndrome in a child with severe Crohn's disease and familial Mediterranean fever. J Crohns Colitis 4(3): 341-344.

29. Unal A, Dursun A, Emre U, Tascilar NF, Ankarali H, et al. (2010) Evaluation of common mutations in the Mediterranean fever gene in Multiple Sclerosis patients: is it a susceptibility gene? J Neurol Sci. 294(1-2): 3842.

30. Unal A, Emre U, Dursun A, Aydemir S (2009) The co-incidence of multiple sclerosis in a patient with familial Mediterranean fever. Neurol India 57(5): 672-673.

31. Alpayci M, Bozan N, Erdem S, Gunes M, Erden M, et al. (2012) The possible underlying pathophysiological mechanisms for development 
of multiple sclerosis in familial Mediterranean fever. Med Hypotheses 78(6): 717-720.

32. Kümpfel T, Gerdes LA, Wacker T, Blaschek A, Havla J, et al. (2012) Familial Mediterranean fever-associated mutation pyrin E148Q as a potential risk factor for multiple sclerosis. Mult Scler 18(9): 1229-1238.

33. Yahalom G, Kivity S, Lidar M, Vaknin-Dembinsky A, Karussis D, et al. (2011) Familial Mediterranean fever (FMF) and multiple sclerosis: an association study in one of the world's largest FMF cohorts. Eur J Neurol 18(9): 1146-1150.

34. Mori S, Yonemura K, Migita K (2013) Familial Mediterranean fever occurring in an elderly Japanese woman with recent-onset rheumatoid arthritis. Intern Med 52(3): 385-388

35. Koca SS, Etem EO, Isik B, Yuce H, Ozgen M, et al. (2010) Prevalence and significance of MEFV gene mutations in a cohort of patients with rheumatoid arthritis. Joint Bone Spine 77(1): 32-35.

36. Migita K, Abiru S, Sasaki O, Miyashita T, Izumi Y, et al. (2012) Coexistence of familial Mediterranean fever and rheumatoid arthritis. Mod Rheumatol 24: 212-216.

37. Erten S, Erzurum C, Kosker TA, Doğan HT, Altunoglu A, et al. (2013) Two cases of familial Mediterranean fever associated with sarcoidosis (Lofgren's syndrome) and rheumatoid arthritis. Int J Rheum Dis 16(3): 373-375.

38. Migita K, Abiru S, Sasaki O, Miyashita T, Izumi Y, Nishino A, et al. (2014) Coexistence of familial Mediterranean fever and rheumatoid arthritis Mod Rheumatol 24(1):212-216.

39. Ceri M, Unverdi S, Altay M, Ureten K, Oztürk MA, et al. (2010) Anticyclic citrullinated peptides positivity rate in patients with familial Mediterranean fever. Clin Exp Rheumatol 28(4 Suppl 60): S58-61.

40. Ayaz NA, Ozen S, Bilginer Y, Ergüven M, Tașkiran E, et al. (2009) MEFV mutations in systemic onset juvenile idiopathic arthritis. Rheumatology (Oxford) 48(1): 23-25.

41. Kaya S, Kaptanoglu E, Elden H, Hizmetli S (2010) Coexistence of familial Mediterranean fever and juvenile idiopathic arthritis with osteoporosis successfully treated with etanercept. Intern Med 49(6): 619-622.

42. Cantarini L, Lucherini OM, Simonini G, Galeazzi M, Baldari CT, et al. (2012) Systemic-onset juvenile idiopathic arthritis complicated by early onset amyloidosis in a patient carrying a mutation in the MEFV gene. Rheumatol Int 32: 465-467.

43. Comak E, Dogan CS, Akman S, Koyun M, Gokceoglu AU, et al. (2013) MEFV gene mutations in Turkish children with juvenile idiopathic arthritis. Eur J Pediatr 172(8): 1061-1067.

44. Rimar D, Rosner I, Rozenbaum M, Zuckerman E (2011) Familial Mediterranean fever: an association with non-alcoholic fatty liver disease. Clin Rheumatol 30(7): 987-991.

45. Inamo Y, Hayashi R, Saito K, Hasegawa M, Nakamura A, et al. (2013) A Japanese pediatric patient with coexisting systemic lupus erythematosus and familial Mediterranean fever. Lupus 22(10):1056-1059.
46. Matsuda M, Kishida D, Tsuchiya-Suzuki A, Fukushima K, Shimojima Y, et al. (2010) Periodic peritonitis due to familial Mediterranean fever in a patient with systemic lupus erythematosus. Intern Med 49: 2259-2262.

47. Yildiz G, Kayatas M, Uygun Y, Timuçin M, Candan F, et al. (2010) Coexistence of systemic lupus erythematosus and familial Mediterranean fever. Intern Med 49: 767-769.

48. Oğuz ID, Gönül M, Cakmak SK, Ozcan N, Gül U, et al. (2014) A case of Beau's lines associated with familial Mediterranean fever. Int J Dermatol 53(2): e121-122.

49. Cetin D, Genç Çetin B, Sentürk T, Sahin Çildağ S, Yllmaz Akdam I, et al. (2015) Coexistence of two rare genetic disorders: Kartagener syndrome and familial Mediterranean fever. Mod Rheumatol 25(2): 312-314.

50. Erten S, Ceylan GG, Altunoğlu A (2012) Concomitance of Gitelman syndrome and familial Mediterranean fever: a rare case presentation. Ren Fail 34(10): 1333-1334.

51. Zizzo C, Colomba P, Albeggiani G, Gallizzi R, Iemolo F, et al. (2013) Misdiagnosis of familial Mediterranean fever in patients with AndersonFabry disease. Clin Genet 83(6): 576-581.

52. Krums LM, Golovanova EV, Khomeriki SG, Varlamicheva AA, Dorofeev AS, et al. (2012) Celiac disease is a 33-year-old man with periodic disease. Eksp Klin Gastroenterol 3: 114-117.

53. Eguchi M, Miyashita T, Shirouzu H, Sato S, Izumi Y, et al. (2013) Coexistence of polymyositis and familial Mediterranean fever. Mod Rheumatol 23(2): 374-378.

54. Bouomrani S, Mesfar R, Ben Ayed M, Guermazi M, Baïli H, et al. (2019) Juvenile dermatomyositis associated to Familial Mediterranean Fever. American Journal of Medical Case Reports 7(8):170-172.

55. Aslan D (2011) Familial Mediterranean fever with a single MEFV mutation: can a deletion resulting in $\alpha$-thalassemia be the cause? J Hum Genet 56(2): 169-171.

56. Miller EB, Friedman JA, Lahav Y, Landau Z (2011) Relapsing polychondritis and familial Mediterranean fever-an association. Clin Rheumatol 30(3): 711-713.

57. Feng J, Zhang Z, Li W, Shen X, Song W, et al. (2009) Missense mutations in the MEFV gene are associated with fibromyalgia syndrome and correlate with elevated IL-1beta plasma levels. PLoS One 4(12): e8480.

58. Kocak G, Kocak E, Yilmaz SR, Koklu S, Duranay M, et al. (2010) MEFV gene mutations in a patient with eosinophilic gastroenteritis. South Med J 103(11): 1170-1172.

59. Clementi A, Cruz ND, Granata A, Virzì GM, Battaglia G, et al. (2013) Secondary amyloidosis in a patient carrying mutations in the familia Mediterranean fever (FMF) and tumour necrosis factor receptor-1 syndrome (TRAPS) genes. Clin Kidney J 6(6): 613-617.

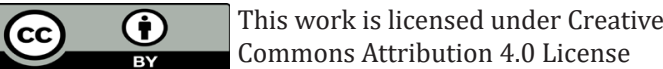

To Submit Your Article Click Here:

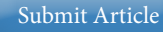

DOI: $10.32474 /$ RRHOAJ.2020.05.000207

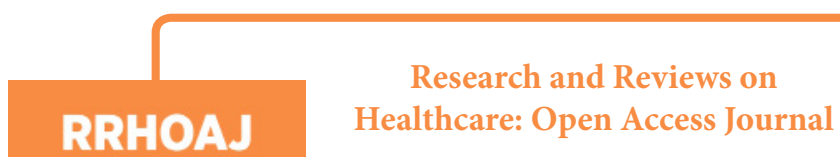

Assets of Publishing with us

- Global archiving of articles

- Immediate, unrestricted online access

- Rigorous Peer Review Process

- Authors Retain Copyrights

- Unique DOI for all articles 